\title{
Role of Glycoproteins during Fruit Ripening and Seed Development
}

\author{
Angela Mendez-Yañez ${ }^{1}$, Patricio Ramos ${ }^{2}$ (D) and Luis Morales-Quintana ${ }^{3, *}$ (D) \\ 1 Multidisciplinary Agroindustry Research Laboratory, Talca 3467987, Chile; amendez.ya@gmail.com \\ 2 Centro de Investigación de Estudios Avanzados del Maule (CIEAM), Universidad Católica del Maule, \\ Talca 3460000, Chile; pramos@ucm.cl \\ 3 Multidisciplinary Agroindustry Research Laboratory, Instituto de Ciencias Biomédicas, \\ Facultad de Ciencias de la Salud, Universidad Autónoma de Chile, Talca 3467987, Chile \\ * Correspondence: luis.morales@uautonoma.cl; Tel./Fax: +56-71-2735699
}

Citation: Mendez-Yañez, A.; Ramos, P.; Morales-Quintana, L. Role of Glycoproteins during Fruit Ripening and Seed Development. Cells 2021, 10 2095. https://doi.org/10.3390/cells 10082095

Academic Editors: Gopinadhan Paliyath and Avtar K. Handa

Received: 22 July 2021

Accepted: 13 August 2021

Published: 15 August 2021

Publisher's Note: MDPI stays neutral with regard to jurisdictional claims in published maps and institutional affiliations.

Copyright: (c) 2021 by the authors. Licensee MDPI, Basel, Switzerland. This article is an open access article distributed under the terms and conditions of the Creative Commons Attribution (CC BY) license (https:// creativecommons.org/licenses/by/ $4.0 /)$.

\begin{abstract}
Approximately thirty percent of the proteins synthesized in animal or plant cells travel through the secretory pathway. Seventy to eighty percent of those proteins are glycosylated. Thus, glycosylation is an important protein modification that is related to many cellular processes, such as differentiation, recognition, development, signal transduction, and immune response. Additionally, glycosylation affects protein folding, solubility, stability, biogenesis, and activity. Specifically, in plants, glycosylation has recently been related to the fruit ripening process. This review aims to provide valuable information and discuss the available literature focused on three principal topics: (I) glycosylations as a key posttranslational modification in development in plants, (II) experimental and bioinformatics tools to analyze glycosylations, and (III) a literature review related to glycosylations in fruit ripening. Based on these three topics, we propose that it is necessary to increase the number of studies related to posttranslational modifications, specifically protein glycosylation because the specific role of glycosylation in the posttranslational process and how this process affects normal fruit development and ripening remain unclear to date.
\end{abstract}

Keywords: fruit ripening; glycoproteins; N-glycosylation; seed development; quality fruit

\section{Introduction}

Glycosylation is the process of adding carbohydrates to a protein and is an essential and important process to produce protein posttranslational modification (PTMs) in eukaryotic cells [1]. Glycosylation is involved in many important cell life processes, such as differentiation, recognition, development, signal transduction, and immune response; additionally, glycosylation affects protein folding, solubility, stability, biogenesis, and activity [2,3]. Moreover, in plants, glycosylation has been related to the fruit ripening process [4-6].

With respect to the biochemical process, glycosylation involves the covalent linkage of a sugar moiety or glycan to a mature protein in the endoplasmic reticulum (ER) and the Golgi apparatus [7]. The biosynthetic pathway of these sugar monomers involved in the glycosylation process overlaps with the biosynthesis of ascorbate as well as with those used for cell wall polysaccharide precursors, including mannose, fucose, xylose, and galactose [3].

The basic molecular machinery participating in protein glycosylation differs slightly between species in which these PTMs occur based on the specificities of some enzyme transferases and hydrolases on the faces of the Golgi in different species. Thus, specific glycosylation events are generated based on residues and particular bonds in each kingdom. Similarly, glycosylation events could change in time and space, depending on biotic or abiotic stress, external conditions, and the genetic background of the plant.

The intrinsic effect of glycosylation in different organisms has been studied. However, current knowledge of complex glycans in plants is very limited. Thus, this review criti- 
cally organizes information from recent years about glycan-specific functions in various biological processes related to fruit development and ripening.

\section{Different Glycosylation Types}

There are three different types of glycosylation: C-glycosylations, $\mathrm{N}$-glycosylation, and $\mathrm{O}$-glycosylation. These types of glycosylation events are distinguished based on the location where the carbohydrate is attached to the amino acid residue of the protein [8]. $C$-glycosylation occurs when the point of glycosylation is the carboxyl group of the tryptophan residue, $\mathrm{N}$-glycosylation occurs when the point of glycosylation is the amino group of the side chain of the asparagine residue, and $O$-glycosylation occurs when the point is the hydroxyl group of the side chains $(2 S, 4 R)$-4-hydroxyproline (Hyp) [9].

\subsection{N-Glycosylations}

$\mathrm{N}$-glycosylations are as posttranslational modification processed in the endoplasmic reticulum and Golgi apparatus [7]. Currently, numerous studies have described Nglycosylations in plants, including the synthesis and molecular machinery involved [10,11]. In all eukaryotes, glycosylation involves a lipid-linked oligosaccharide and a glycan block that binds to asparagine $(\mathrm{N})$ followed by any residue $(\mathrm{X})$ and then serine or threonine $(\mathrm{S} / \mathrm{T})$ (the sequence is termed NXS/T) and is the substrate of the enzyme oligosaccharyltransferase [12]. Modifications realized by glycosyltransferases and hydrolases enzymes in different Golgi faces produce an $\mathrm{N}$-glycosylation event that promotes a particular biological role.

In contrast to mammals, insects, or yeasts, glycosylation events in plants involve specific glycans, such as xylose and fucose [13]. For example, $\beta 1,2$-xylosyltransferase and $\alpha 1,3$-fucosyltransferase enzymes. Mutation or silencing of genes that code for the two enzymes mentioned above to produce viable plants and phenotypes under laboratory conditions [14]. Nagashima et al. [3] showed that the functions of $\mathrm{N}$-glycosylation events in plants are related to the protein folding, protein receptors, biogenesis, cell wall biosynthesis, and salt stress tolerance. A summary of the main evidence related to $\mathrm{N}$-glycosylations in plants is shown in Table 1. Additionally, it has been recently found that $\mathrm{N}$-glycosylations vary in space and time. Thus, the proportional variability of the $\mathrm{N}$-glycans and subcellular distribution has been verified [15].

Table 1. Summary of principal research about $N$-glycosylation and O-glycosylation in plant proteins since 2000. This table contains glycosylated proteins, glycosyltransferases, glycosylhydrolases, and transglycosylase.

\begin{tabular}{|c|c|c|c|c|}
\hline $\begin{array}{l}\text { Enzyme or } \\
\text { Protein Type }\end{array}$ & Organism & Enzyme & Function & Reference \\
\hline \multirow{4}{*}{$\begin{array}{l}\text { Glycosylated } \\
\text { enzymes } \\
\text { and proteins }\end{array}$} & Arabidopsis thatiana & AtERO1 & $\begin{array}{l}\text { Identification of } N \text {-glycosylation } \\
\text { sites of ER oxidoreductin- } 1 .\end{array}$ & [16] \\
\hline & Arabidopsis thaliana & AtERO2 & $\begin{array}{l}\text { Identification of } N \text {-glycosylation } \\
\text { sites of ER oxidoreductin- } 2 \text {. }\end{array}$ & {$[16]$} \\
\hline & Nicotiana benthamiana & $\begin{array}{l}\text { Cannabichromenic } \\
\text { acid synthase }\end{array}$ & $\begin{array}{l}\text { Mutagenesis is a glycosylated } \\
\text { enzyme to produce } \\
\text { tetrahydrocannabinolic } \\
\text { acid in tobacco. }\end{array}$ & [17] \\
\hline & Pyrus bretschneideri & $\begin{array}{l}\text { Fasciclin-like } \\
\text { arabinogalactan } \\
\text { protein family }\end{array}$ & $\begin{array}{l}\text { Identification and function analysis } \\
\text { of this family of proteins. }\end{array}$ & [18] \\
\hline \multirow{4}{*}{ Transferase } & $\begin{array}{l}\text { Solanum tuberosum } \mathrm{L} . \\
\text { Nicotiana tabacum L. } \\
\text { Arabidopsis thaliana }\end{array}$ & $\begin{array}{c}N \text {-acetyl } \\
\text { glucosaminyltransferase I }\end{array}$ & $\begin{array}{l}\text { Enzyme that begins the complex } \\
N \text {-linked glycans. }\end{array}$ & [19] \\
\hline & Nicotiana benthamiana & $\begin{array}{c}N \text {-acetyl } \\
\text { glucosaminyltransferase I }\end{array}$ & $\begin{array}{l}\text { Glycoengineering to produce } \\
\text { human enzyme glucocerebrosidase }\end{array}$ & [20] \\
\hline & Nicotiana benthamiana & $\alpha 1,3$-fucosyltransferase & $\begin{array}{l}\text { Inhibition to produce human-like } \\
\qquad N \text {-glycan structure. }\end{array}$ & {$[21]$} \\
\hline & Nicotiana benthamiana & $\beta 1,2$-xylosyltransferase & $\begin{array}{l}\text { Inhibition to produce human-like } \\
\text { N-glycan structure. }\end{array}$ & [21] \\
\hline
\end{tabular}


Table 1. Cont.

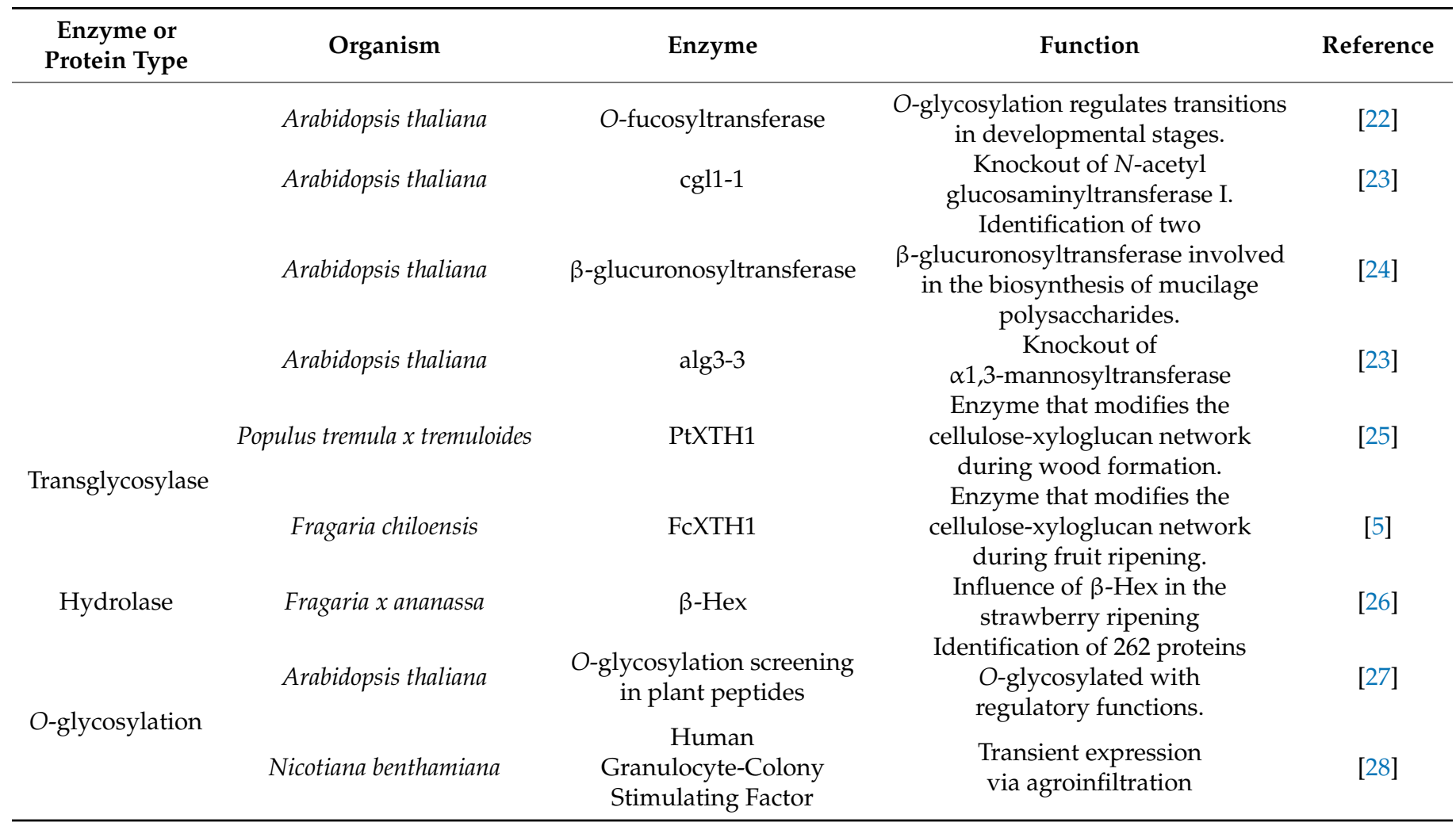

\subsubsection{N-Glycosylation and Plant Development}

Reports of $\mathrm{N}$-glycosylated enzymes, related to fruit ripening and the shelf life of fruit are scarce. Nevertheless, efforts have been directed to understanding the role of $\mathrm{N}$-glycosylation in plant development (Figure 1). For example, mutants related to photosynthesis from Arabidopsis thaliana enzymes $\alpha 1,3$-fucosyltransferase (alg3-3) and $N$-acetyl glucosaminyltransferase I (cgl1-1), which have defects in Dol-PP-linked glycans and an absence of complex glycans, respectively, were studied [23]. In these mutants, a decrease in the capacity to capture and transfer excitation energy was observed by increasing light levels, a decrease in dry biomass, and a decrease in photosynthetic capacity and functional decomposition of chloroplast-located protein [23]. In calcium signal mutants of $A$. thaliana, such as cce 2 and cc3, a decrease in the enzymatic function of proteins encoded by the alleles cce $2 /$ cc 3 was observed, where ALG3, which codes for the $\alpha-1,3$-mannosyltransferase enzyme, is responsible for the assembly of the first glycan Glc3Man9GlcNAc in the endoplasmic reticulum. Glycosylation defects compromise the immune response of plants, altering the molecular patterns related to defense against microorganism responses, and defects in glycosylation can affect microorganism virulence [29]. In this sense, plant organisms present molecular patterns associated with pathogens (MAMPs/PAMPs), which activate a series of molecular events that are triggered when producing an infection or damage; these patterns of recognition can be lipopolysaccharide, peptidoglycan, extracellular proteins, extracellular ATP or polygalacturonates [29]. In the case of MAMP signaling, plants with low levels of recognition patterns can be susceptible to pathogens, as in the case of tomatoes, such as Pseudomonas syringae. As described by Lin et al. [30], infection occurs through the interaction of the host cell surface proteins and the pathogen, where a large portion of these extracellular proteins is glycosylated [30]. This mechanism explains how glycosylation in plants can act as a barrier against pathogens or induce resistance [30].

Mutations in key enzymes of the $\mathrm{N}$-glycosylation pathway are viable in some plant species but lethal in other plant species. The reason for this difference remains unknown [31]. However, when investigating the molecular responses of the plant, internal (as the geno- 
type) and external (as the environment) events that could indirectly affect the expression of certain genes must be considered.

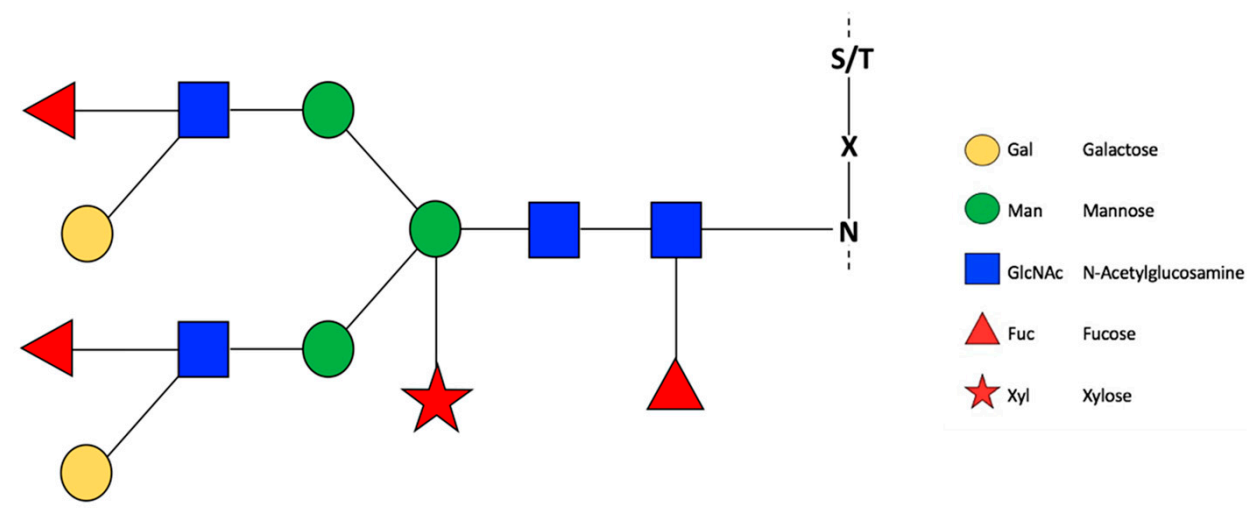

Figure 1. General representation of N-glycosylation in plants. Glycans are represented according to Consortium for Functional Glycomics (CFG). Recovered with modifications of Wang et al. [32].

\subsubsection{N-Glycosylation and Fruit Ripening}

Different efforts have been made to understand the relationship between $\mathrm{N}$-glycosylation and fruit ripening. In this regard, Ghosh et al. [33] evidenced that silencing through RNA interference in $\alpha$-mannosidase ( $\alpha$-Man) and $\beta$-D- $N$-acetylhexosaminidase ( $\beta$-Hex), two $N$-glycoprotein modifying enzymes present in Capsicum annuum fruits, delayed fruit deterioration until seven days post-harvest, providing fruits up to twice as firm as the control. The relationship of the $\beta$-Hex enzyme in ripening fruit was determined in Fragaria $x$ ananassa (commercial strawberry). Transcript levels of two genes that code for two members of this enzyme family, increase during ripening, and the inhibition of its enzymatic activity with alginate oligosaccharides allow us to extend the shelf life of the fruit [26] (Table 1).

Similar results were obtained by Meli et al. [34], who showed that $\alpha$-Man and $\beta$-Hex suppression in Solanum lycopersycum produced an increase in firmness ( 2.5 fold greater than that of the control) and consequently prolonged the shelf life by 30 days.

Varki [35], described a general classification of the biological role of glycans: (1) Structural and modulatory roles: Glycoproteins help the cell perceive and interact with the surrounding microenvironment. Polysaccharides, for example, are used to organize the membrane and the extracellular matrix and provide structural support, adhesion, protection, and elasticity to the cell. Specifically, the cell wall changes dynamically based on the action of enzymes with catalytic activity in cells, different sugars in the cell wall, and glycans in proteins. Similarly, in some cases, glycosylation affects the diffusion and solubility of macromolecules and provides a defense against pathogens and proteases. (2) Intrinsic recognition: Glycoproteins facilitate internal communication, triggering cascades of signals or reactions in response to processes that occur inside the cell. For example, internal recognition of some internal signals triggers endocytosis or phagocytosis. (3) Extrinsic recognition: Interaction with pathogens and symbionts. Glycans participate mainly in interaction and recognition. Specifically, microorganisms recognize glycans, and the host organism simultaneously produces glycans as defense mechanisms. On the other hand, the adhesins produced by microorganisms facilitate their ability to bind to the host cell. Regarding viruses, glycoproteins such as hemagglutinins, allow viruses to achieve success in infection by agglutinating erythrocytes. (4) Molecular mimicry of host glycans: Evolution has allowed pathogens and hosts to change in such a way that the pathogen can mimic some of its molecular mechanisms, such as host-specific glycosylation events and some host cell-specific molecular patterns (SAMPs). On the other hand, some microorganisms are capable of capturing free glycans and adding them to their proteins to mask them 
within the host cell. Within each category, a list of specific biological roles related to specific glycosylation events has been reported.

Recently, it has been reported that the $\mathrm{N}$-glycoproteome of a plant changes in space and time. Zhang et al. [36] described the glycoproteome of two contrasting fruit stages (ripe stage contrasting with green stage) of Solanum lycopersicum. Comparison of the $\mathrm{N}$ glycoproteome in both stages showed $553 \mathrm{~N}$-glycosites and $363 \mathrm{~N}$-glycoproteins. Of these, $252 \mathrm{~N}$-glycosites and $191 \mathrm{~N}$-glycoproteins were differentially expressed between the two stages. Similarly, the $\mathrm{N}$-glycoproteome has been used as a powerful technique to analyze $\mathrm{N}$-glycoproteins and $\mathrm{N}$-glycosites in tomato fruits under saline stress conditions, which led to a decrease in $\mathrm{N}$-glycosites. This evidence indicates that $\mathrm{N}$-glycosylations are reprogrammed under stress conditions. For example, under salt stress conditions, glycoproteins could alter their folding and/or change the activity level [36]. The loss of glycans in proteins can be mediated by enzymes that cleave the glycosidic bonds in the branches of glycans, such as $N^{4}$ ( $N$-acetyl-glucosaminyl) asparagine amidase (PNGase) and endo $N$-acetyl-beta-D-glucosaminidase (ENGase) (Figure 2). In young and developing tissues, such as apical buds, flowers, and leaf blades, PNGase and ENGase enzymes are mostly active but exhibit different levels of gene expression. In the fruit ripening stage in S. lycopersicum fruits, the transcript levels of these enzymes together with other proteases are significantly decreased [37].

A)

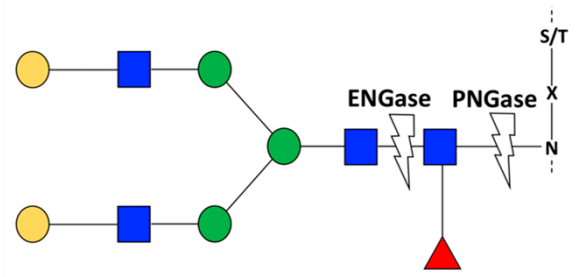

B)
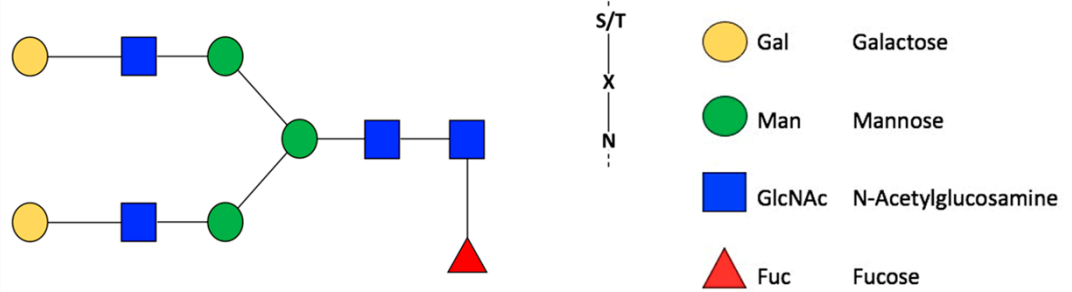

C)
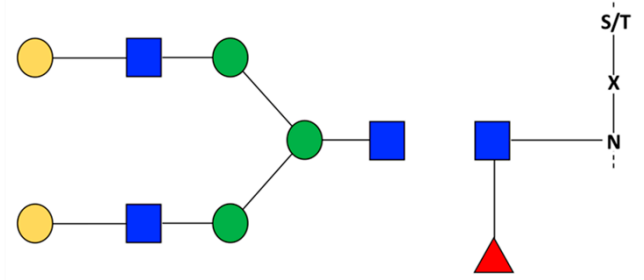

Figure 2. Schematic representation of the EnGase and PNGase enzyme activity. (A) PNGase F has activity in the glycosidic bond between asparagine amino acid and GlcNAc glycan, while, ENGase has activity in the glycosidic bond between two GlcNAc glycans. As result, with PNGase F glycosylation is completely cleaved (showed in B). ENGase leaves a GlcNAc attached to the asparagine amino acid (showed in C). Glycans are represented according to Consortium for Functional Glycomics (CFG). Recovered with modifications of Karav et al. [38] and Fairbanks [39].

In addition to studying enzymes with deglycosylase activity, such as $\alpha$-Man and $\beta$-Hex, other enzymes that are related to plant cell wall metabolism have been investigated during the fruit ripening process. Méndez-Yáñez et al. [5] biochemically characterized the FcXTH1 enzyme (Table 1). This enzyme is related to the fruit ripening process, specifically with cell wall remodeling and fruit softening in different fruits, including Chilean strawberry [5]. To describe the effect of glycosylation on enzyme activity, the authors 
used bioinformatics tools, such as protein modeling, in silico protein-ligand interaction analysis by molecular docking and molecular dynamics simulations. All these studies were validated by kinetic and biochemical assays. The principal result was that glycosylated proteins are more stable than non-glycosylated proteins [5]. In addition, this finding is not the only example of the positive effect of glycosylation on XTH activity; the same enzyme is expressed in heterologous systems and exhibits changes in biochemical parameters and enzyme stability [5]. For example, in PttXET16A, an XTH of Populus tremula $x$ tremuloides, site-directed mutagenesis studies were performed (substitution of serine for asparagine in the glycosylation site), and the mutation did not produce a significant reduction in XET activity [25]. Additionally, the removal of $N$-glycan by endoglycosidase $\mathrm{H}$ (Endo $\mathrm{H}$ ) treatment did not significantly modify the XET activity in PttXET16A [25]. In contrast, the activity levels of AtXTH22 and AtXTH24, two XTH enzymes identified in A. thaliana, were significantly reduced by PNGase F treatment [40]. Similar results showed the stability of the HvXET6 enzyme during storage at $4{ }^{\circ} \mathrm{C}$. The analysis revealed that HvXET6 treated with PNGase F gradually lost its activity, with a decline of approximately $20-25 \%$ reduction in activity after 6 days. However, when HvXET6 was treated with Endo H, the enzyme remained almost fully active even after 6 days of storage [41]. Interestingly, Endo H cleaves the chitobiose core of high mannose $N$-linked glycoproteins, whereas PNGase F releases almost all types of $N$-linked glycans between the innermost GlcNAc and asparaginyl residues [41]. The authors indicate that the HvXET6 protein requires only one GlcNAc to maintain XET activity [41]. However, this affirmation is not completely true because the kinetic parameters $\left(\mathrm{K}_{\mathrm{M}}\right.$ and $\mathrm{k}_{\mathrm{cat}}$ ) of the HvXET6 enzyme treated with PNGase $\mathrm{F}$ (after $16 \mathrm{~h}$ of incubation at $20^{\circ} \mathrm{C}$ ) differ from those of glycosylated $\mathrm{HvXET}^{2}$ : the kcat/KM ratio was increased by approximately $40 \%$ [41]. It is thus possible that $N$-glycans have a differential role in XET activity, and this apparent crucial role is more important for some XTHs than others. However, a clear understanding of the reasons for this difference is lacking.

Recently, reported research on complex $N$-glycans has focused on $N$-glycosylation enzyme pathway silencing-mediated RNAi. Specifically, a reduction in $N$-acetyl-glucosaminyltransferase I (GNTI) activity produces necrotic stems, early fruit abscission, incomplete ripening, and susceptibility to infections [31]. In plants treated with $\alpha$-mannosidase II (MANII) RNAi, the fruits showed a normal appearance. However, the fruits did not contain seeds or only a few enlarged seeds, and rolled leaves were observed in the reproductive stage [31].

\subsection{O-Glycoproteins in Fruits and a World Not Yet Explored}

The first report describing $O$-glycosylations was published by Torres et al. [42]. Oglycosylations are less studied than $N$-glycosylations, and many processes and studies related to their mechanism of action have not yet been described. The cellular pathways involved in O-glycosylation are unclear; however, some studies observed the importance of repeated proline (Pro) residues in the different glycans. Although not all the components of the pathway are clear, we currently know that O-glycosylation differs in mammals and plants. Specifically, the first hydroxylation of oxygen occurs in a Ser or Thr residue in mammals, versus a Pro residue in plants [43]. The change in Pro to hydroxyproline (Hyp) (Figure 3) is catalyzed by proline hydroxylase enzymes (P4Hs). The group of hydroxyproline-rich glycoproteins in plants is formed by: extensins (EXTs), arabinogalactan proteins (AGPs), and proline-rich proteins (PRPs) [43]. Pro hydroxylation produces a change in the molecular charge of the microenvironment and generates a conformational change and interaction between proteins to produce hydroxyl groups, allowing posttranslational modifications. Thus, Hyp is a signal that the molecular machinery recognizes as a flag, indicating the site where O-glycosylation must be performed. 
Reports of O-Glycosylations in Plants

In A. thaliana, it has been demonstrated that $O$-glycosylation, specifically arabinosylation in EXTs, is essential to root hair elongation. Mutant lines deficient in the $\mathrm{P} 4 \mathrm{H}$ gene exhibited a lower root hair size compared with controls [44]. Recently, the first large-scale $\mathrm{O}$-glycosylation study in plants was reported, where Xu et al. [27] found $262 \mathrm{O}$-glycosylated proteins with an important role in $A$. thaliana. However, the role of $O$-glycosylation in fruit ripening has not yet been determined.

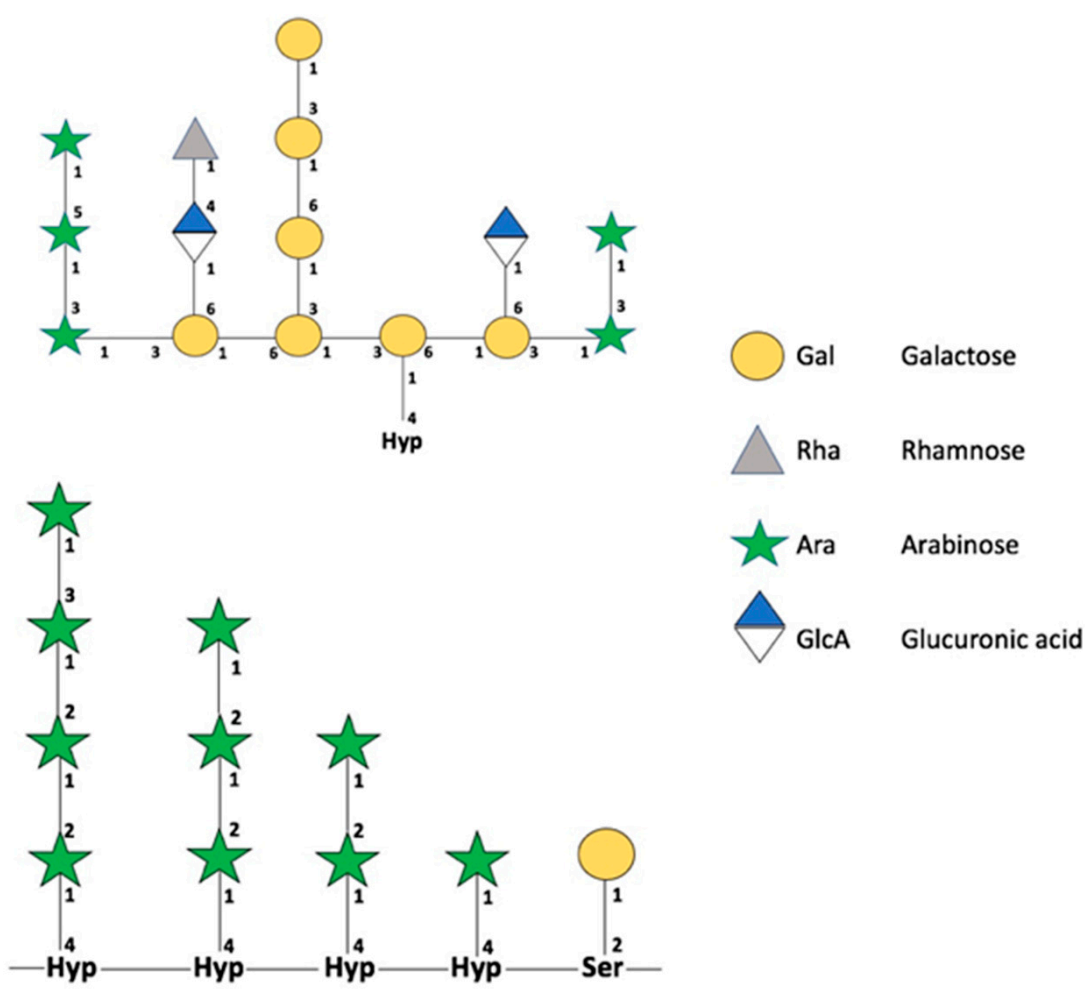

Figure 3. Schematic representation of $O$-glycans. The upper image summarizes the possible structures found in $O$-glycans in type II AGPs. The bottom image summarizes the possible $O$-glycosylations in plant EXTs. Representations of monosaccharides are based on the official notation of the Consortium for Functional Glycomics (CFG). Retrieved with modifications from Tan et al. [45] and NguemaOna et al. [46].

\section{Experimental Techniques to Identify $\mathrm{N}$ - and $\mathrm{O}$-Glycosylations}

Ruiz-May et al. [47] reviewed analytical and classical technologies to identify and characterize $N$-glycosylations in plants. Since then, many publications have used these and other novel technologies to study the $\mathrm{N}$-glycoproteome in plants. For example, mass spectrometry (MS) remains the primary experimental technique used to characterize $N$ glycosylations in eukaryotes. The technique typically used to recognize the glycosylation events present in a protein requires deglycosylation, which leads to the loss of information. This process makes it impossible to know the specific point to which a certain glycosylation was attached. Therefore, the polypeptide fragmentation technique, which involves hydrolysis and subsequent analysis of the glycosylated sites and their respective glycans, remains an excellent alternative [48]. Stravenhagen et al. [49] proposed a workflow for the site-specific analysis of an $\mathrm{N}$-glycosylation or O-glycosylation site. Additionally, a consensus sequence is necessary for the identification of potentially $\mathrm{N}$-glycosylated sites, but the occupation of an N-glycosylation site is not mandatory [50]. 
The current experimental methods for O-glycan characterization and separation have been summarized in the work of Wilkinson and Saldova [51], where they describe the main glycan release methods: enzymatic, reductive $\beta$-elimination, nonreductive by $\beta$ elimination (hydrazinolysis and thousand alkalines), and oxidative release of natural glycans. On the other hand, the main methods for the separation and analysis of glycans include high-performance liquid chromatography (HPLC); UPLC, or UHPLC (Ultra HighPerformance Liquid Chromatography); exoglycosidase arrays; mass spectrometry (MS); MS ion fragmentation; capillary electrophoresis (CE); nuclear magnetic resonance (NMR) spectroscopy; and lectin affinity.

Mewono et al. [52] performed a review of three chemical inhibitors of the enzymatic activity of prolyl 4-hydroxylase (P4H): (1) 3,4-dehydro-L-proline, an analog of Pro that is capable of being incorporated into the polypeptide chain; (2) ethyl 3,4-dehydroxy benzoate, which binds to the active site of the $\mathrm{P} 4 \mathrm{H}$ enzyme, and (3) $\alpha$ - $\alpha$-dipyridyl, a chelator of the key $\mathrm{P} 4 \mathrm{H}$ cofactor. This technique could be useful for studying $\mathrm{O}$-glycosylated proteins.

\section{Bioinformatics Glycosylations Tools in Plants}

A large number of online applications and databases are available to perform glycoinformatics. Muthu et al. [53], suggested a classification of databases with bioinformatics resources grouped in three categories: (1) proteins; (2) enzymes and pathways to build glycans, and (3) carbohydrate structural databases. The authors provide a list of tools and online resources to study glycosylations. For molecular modeling of glycosylated proteins, Frank and Schloissnig [54] provided a pipeline and valuable details to the design of a protein with glycosylation. A force field used for molecular modeling in an environment with carbohydrates has been developed and detailed by Park et al. [55].

Combining experimental data with in silico analysis [56] is a useful technique that can potentially reduce research times required to model a glycoprotein and perform subsequent minimization and molecular dynamics analyses. Research published based on this type of combined technique, increases confidence in dry-lab technologies, reducing experimental search times.

Specifically, in plants, different resources currently exist for glycosylations studies. Johnson et al. [57] developed a pipeline to identify HRGPs in plants to facilitate focused efforts on the search and subsequent study of $O$-glycosylated proteins. Another important resource available online is Plant PTM Viewer (https:/ / www.psb.ugent.be/webtools/ptmviewer/, accessed on 4 August 2021) [58]. Using this resource, a sequence can be analyzed, and the putative sites of posttranslational modifications, including glycosylations, can be predicted. The database is supported by experimental data, and information included in this database has been deposited in other databases, such as UniProt, PubMed, and InterPro. The main recommendation when analyzing posttranslational modifications is to use different databases and applications in conjunction with the literature and previous experimental results, if available. Although algorithms and results obtained and generated by machines are quite reliable, it is necessary to remember that the biological interpretation has not yet been fully elucidated.

Phyton scripts are also very useful for glycosylation studies. For example, Glycosylator is a phyton framework for the investigation of glycoproteins using the CHARMM force field [59]. However, for novices in the field of informatics, various applications, programs, and web servers with an easy-to-use graphical interface are available on the internet.

To study glycosylated proteins in silico (Figure 4), we proposed the following steps: (1) All the biological and experimental information that is based on the enzyme or protein under study must be considered; (2) Evaluate or predict its secondary structure; (3) Analyze the putative glycosylation sites and whether these sites could be glycosylated based on their structure; (4) Once the glycosylated sites are defined, build the glycan and the glycosylated protein to be studied, and (5) Choose force fields for molecular dynamics and simulation, that also consider the parameters for glycan structures. 


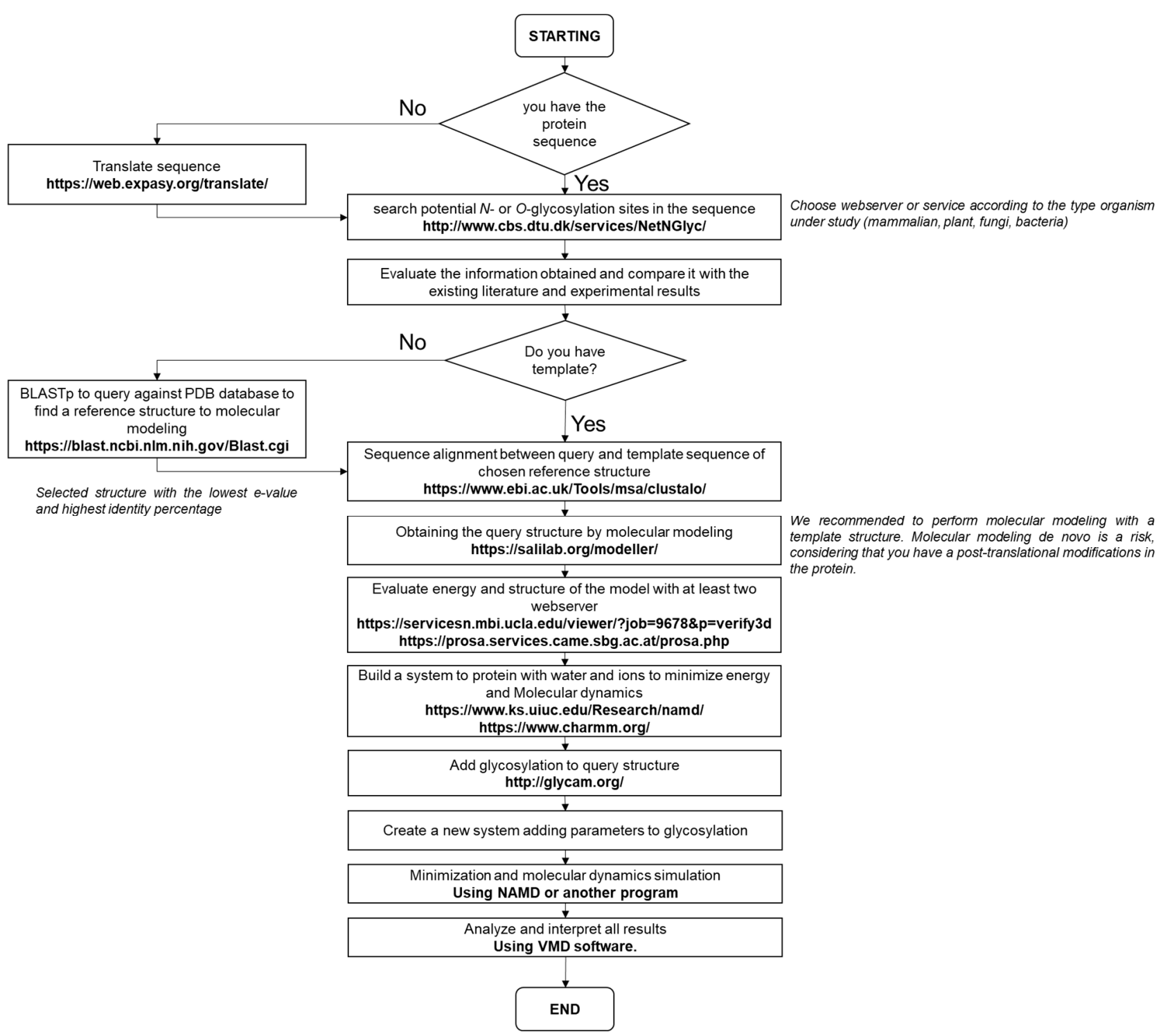

Figure 4. The pipeline proposal is based on the comparative modeling methodology. The pipeline was designed according to the methodology described by Méndez-Yáñez et al. [5].

\section{New Perspectives and Challenges}

Although potential activity or gene expression can be evidenced a priori, once the protein has been transcribed and located in the site where it will perform its function within the cell, it is possible to elucidate whether a gene has an impact at biological and biochemical levels. Clearly, information regarding glycosylated proteins, transglycosylase and hydrolase enzymes, glycomes, and other investigations related to fruit ripening and postharvest are lacking. In addition, the importance of studying $O$-glycosylations in relation to fruit ripening has not yet been determined. However, we believe that in the near future, glycomics will be an important area of study, similar to other omics.

The relationship of this type of PTM and fruit ripening could undoubtedly be the key to prolonging the useful life of the fruit or to understanding the essential molecular events for optimal fruits developments.

Author Contributions: Conceptualization, L.M.-Q. and A.M.-Y.; investigation, L.M.-Q., P.R. and A.M.-Y.; resources, L.M.-Q. and P.R.; data curation, L.M.-Q. and P.R.; writing-original draft preparation, L.M.-Q. and A.M.-Y.; writing—review and editing, L.M.-Q. and P.R.; visualization, A.M.-Y.; 
supervision, L.M.-Q.; project administration, L.M.-Q. and P.R.; funding acquisition, L.M.-Q. and P.R. All authors have read and agreed to the published version of the manuscript.

Funding: The Agencia Nacional de Investigación y Desarrollo (ANID, Chile) [grants REDES \#190093 to L.M.-Q.; REDES \#190078 to P.R.; FONDECYT \#1211057 to P.R.] supported the work. The funders had no role in study design, data collection, and analysis, decision to publish, or preparation of the manuscript.

Institutional Review Board Statement: Not applicable.

Informed Consent Statement: Not applicable.

Data Availability Statement: Not applicable.

Conflicts of Interest: The authors declare no conflict of interest.

\section{References}

1. Wang, P.; Li, X.; Wang, Y.; Wang, W.; Tian, S.; Qin, G. Redox proteomic analysis reveals the involvement of oxidative posttranslational modification in tomato fruit ripening. Postharvest Biol. Technol. 2021, 178, 111556. [CrossRef]

2. Hebert, D.N.; Lamriben, L.; Powers, E.T.; Kelly, J.W. The intrinsic and extrinsic effects of N-linked glycans on glycoproteostasis. Nat. Chem. Biol. 2014, 10, 902-910. [CrossRef]

3. Nagashima, Y.; von Schaewen, A.; Koiwa, H. Function of N-glycosylation in plants. Plant Sci. 2018, 274, 70-79. [CrossRef] [PubMed]

4. Nakamura, K.; Inoue, M.; Maeda, M.; Nakano, R.; Hosoi, K.; Fijiyama, K.; Kimura, Y. Molecular cloning and gene expression analysis of tomato endo- $\beta-\mathrm{N}$-acetylglucosaminidase, an endoglycosidase involved in the production of high-mannose type free $\mathrm{N}$-glycans during tomato fruit ripening. Biosci. Biotechnol. Biochem. 2009, 73, 461-464. [CrossRef]

5. Méndez-Yáñez, A.; Beltrán, D.; Campano-Romero, C.; Molinett, S.; Herrera, R.; Moya-León, M.A.; Morales-Quintana, L. Glycosylation is important for FcXTH1 activity as judged by its structural and biochemical characterization. Plant Physiol. Biochem. 2017, 119, 200-210. [CrossRef]

6. Zhang, X.; Tang, H.; Du, H.; Liu, Z.; Bao, Z.; Shi, Q. Comparative N-glycoproteome analysis provides novel insights into the regulation mechanism in tomato (Solanum lycopersicum L.) During fruit ripening process. Plant Sci. 2020, 293, 110413. [CrossRef] [PubMed]

7. Pattison, R.J.; Amtmann, A. N-glycan production in the endoplasmic reticulum of plants. Trends Plant Sci. 2009, 14, 92-99. [CrossRef]

8. Tegl, G.; Nidetzky, B. Leloir glycosyltransferases of natural product C-glycosylation: Structure, mechanism and specificity. Biochem. Soc. Trans. 2020, 48, 1583-1598. [CrossRef]

9. Gorres, K.L.; Raines, R.T. Prolyl 4-hydroxylase. Crit. Rev. Biochem. Mol. Biol. 2010, 45, 106-124. [CrossRef]

10. Lannoo, N.; Van Damme, E.J. Review/N-glycans: The making of a varied toolbox. Plant Sci. 2015, 239, 67-83. [CrossRef]

11. Strasser, R. Plant protein glycosylation. Glycobiology 2016, 26, 926-939. [CrossRef]

12. Kern, N.R.; Lee, H.S.; Wu, E.L.; Park, S.; Vanommeslaeghe, K.; MacKerell, A.; Klauda, J.B.; Jo, S.; Im, W. Lipid-linked oligosaccharides in membranes sample conformations that facilitate binding to oligosaccharyltransferase. Biophys. J. 2014, 107, $1885-1895$. [CrossRef]

13. Strasser, R. Biological significance of complex N-glycans in plants and their impact on plant physiology. Front. Plant Sci. 2014, 5, 363. [CrossRef]

14. Montero-Morales, L.; Steinkellner, H. Advanced plant-based glycan engineering. Front. Bioeng. Biotechnol. 2018, 6. [CrossRef] [PubMed]

15. Zeng, W.; Ford, K.L.; Bacic, A.; Heazlewood, J.L. N-linked glycan micro-heterogeneity in glycoproteins of arabidopsis. Mol. Cell. Proteom. 2018, 17, 413-421. [CrossRef]

16. Fan, F.; Zhang, Q.; Lu, D. Identification of N-glycosylation sites on AtERO1 and AtERO2 using a transient expression system. Biochem. Biophys. Res. Commun. 2020, 533, 481-485. [CrossRef] [PubMed]

17. Geißler, M.F. Metabolic Engineering of Cannabinoid Biosynthesis in Tobacco. Ph.D. Thesis, Technische Universität Darmstadt, Dramstadt, Germany, 2021.

18. Li, X.; Cheng, M.; Tang, C.; Zhu, X.; Qi, K.; Zhang, S.; Wu, J.; Peng, W. Identification and function analysis of fascicles-like arabinogalactan rptoein family genes in pear (Pyrus bretschneideri). Plant Syst. Evol. 2021, 307, 48. [CrossRef]

19. Wenderoth, I.; von Schaewen, A. Isolation and characterization of plant N-acetyl glucosaminyltransferase I (GntI) cDNA sequences. Functional analyses in the arabidopsis cgl mutant and in antisense plants. Plant Physiol. 2000, 123, 1097-1108. [CrossRef]

20. Limkul, J.; Misaki, R.; Kato, K.; Fujiyama, K. The combination of plant translational enhancers and terminator increase the expression of human glucocerebrosidase in Nicotiana benthamiana plants. Plant Sci. 2015, 240, 41-49. [CrossRef] [PubMed] 
21. Strasser, R.; Stadlmann, J.; Schähs, M.; Stiegler, G.; Quendler, H.; Mach, L.; Glössl, J.; Weterings, K.; Pabst, M.; Steinkellner, H. Generation of glyco-engineered Nicotiana benthamiana for the production of monoclonal antibodies with a homogeneous human-like N-glycan structure. Plant Biotechnol. J. 2008, 6, 392-402. [CrossRef]

22. Mutanwad, K.V.; Zangl, I.; Lucyshyn, D. Arabidopsis O-fucosyltransferase SPINDLY regulates root hair patterning independently of gibberellin signaling. Development 2020, 147. [CrossRef]

23. Jiao, Q.-S.; Niu, G.-T.; Wang, F.-F.; Dong, J.-Y.; Chen, T.-S.; Zhou, C.-F.; Hong, Z. N-glycosylation regulates photosynthetic efficiency of Arabidopsis thaliana. Photosynthesis 2020, 58, 72-79. [CrossRef]

24. Ajayi, O.O.; Held, M.A.; Showalter, A.M. Two $\beta$-glucuronosyltransferases involved in the biosynthesis of type II arabinogalactans function in mucilage polysaccharide matrix organization in Arabidopsis thaliana. BMC Plant Biol. 2021, 21, 1-19. [CrossRef]

25. Kallas, A.M.; Piens, K.; Denman, S.E.; Henriksson, H.; Faldt, J.; Johansson, P.; Brumer, H.; Teeri, T.T. Enzymatic properties of native and deglycosylated hybrid aspen (Populus tremulaxtremuloides) xyloglucan endotransglycosylase 16A expressed in Pichia Pastor. Biochem. J. 2005, 390, 105-113. [CrossRef] [PubMed]

26. Bose, S.K.; He, Y.; Howlader, P.; Wang, W.; Yin, H. The N-glycan processing enzymes beta-D-N acetylhexosaminidase are involved in ripening-associated softening in strawberry fruit. J. Food Sci. Technol. 2020, 58, 621-631. [CrossRef] [PubMed]

27. Xu, S.; Bi, Y.; Shrestha, R.; Zhang, Z.; Burlingame, A.; Wang, Z. Nutrient sensing in plants by O-GlcNAcylation and O-Fucosylation. FASEB J. 2021, 35. [CrossRef]

28. Ramirez-Estrada, K.; Castillo, N.; Lara, J.A.; Arró, M.; Boronat, A.; Ferrer, A.; Altabella, T. Tomato UDP-glucose sterol glycosyltransferases: A family of developmental and stress regulated genes that encode cytosolic and membrane-associated forms of the enzyme. Front. Plant Sci. 2017, 8, 984. [CrossRef] [PubMed]

29. Trempel, F.; Kajiura, H.; Ranf, S.; Grimmer, J.; Westphal, L.; Zipfel, C.; Scheel, D.; Fujiyama, K.; Lee, J. Altered glycosylation of exported proteins, including surface immune receptors, compromises calcium and downstream signaling responses to microbe-associated molecular patterns in Arabidospis thaliana. BMC Plant Biol. 2016, 16, 31. [CrossRef] [PubMed]

30. Lin, B.; Qing, X.; Liao, J.; Zhuo, K. Role of protein glycosylation in host-pathogen interaction. Cells 2020, 9, 1022. [CrossRef] [PubMed]

31. Kaulfürst-Soboll, H.; Mertens-Beer, M.; Brehler, R.; Albert, M.; von Schaewen, A. Complex n-glycans are important for normal fruit ripening and seed development in tomato. Front. Plant Sci. 2021, 12, 175. [CrossRef] [PubMed]

32. Wang, P.; Wang, H.; Gai, J.; Tian, X.; Zhang, X.; Lv, Y.; Jian, Y. Evolution of protein N-glycosylation process in Golgi apparatus which shapes diversity of protein N-glycan structures in plants, animals and fungi. Sci. Rep. 2017, 7, 40301. [CrossRef]

33. Ghosh, S.; Meli, V.S.; Kumar, A.; Thakur, A.; Chakraborty, N.; Chakraborty, S.; Datta, A. The N-glycan processing enzymes $\alpha$-mannosidase and $\beta$-D-N-acetylhexosaminidase are involved in ripening-associated softening in the non-climateric fruits of capsicum. J. Exp. Bot. 2010, 62, 571-582. [CrossRef]

34. Meli, V.S.; Ghosh, S.; Prabha, T.N.; Chakraborty, N.; Chakraborty, S.; Datta, A. Enhancement of N-glycan processing enzymes. Proc. Natl. Acad. Sci. USA 2010, 107, 2413-2418. [CrossRef]

35. Varki, A. Biological roles of glycans. Glycobiology 2016, 27, 3-49. [CrossRef] [PubMed]

36. Zhang, X.; Tang, H.; Du, H.; Bao, Z.; Shi, Q. Sugar metabolic and N-glycosylated profiles unveil the regulatory mechanism of tomato quality under salt stress. Environ. Exp. Bot. 2020, 177, 104145. [CrossRef]

37. Faugeron, C.; Mollet, J.-C.; Karamanos, Y.; Morvan, H. Activities of de-N-glycosylation are ubiquitously found in tomato plant. Acta Physiol. Plant. 2006, 28, 557-565. [CrossRef]

38. Karav, S.; Casaburi, G.; Arslan, A.; Kaplan, M.; Sucu, B.; Frese, S. N-glycans from human milk glycoproteins are selectively released by an infant gut symbiont in vivo. J. Funct. Foods 2019, 61. [CrossRef]

39. Fairbanks, A.J. The ENGases: Versatile biocatalysts for the production of homogeneous N-linked glycopeptides and glycoproteins. Chem. Soc. Rev. 2017, 46, 5128-5146. [CrossRef] [PubMed]

40. Campbell, P.; Braam, J. In vitro activities of four xyloglucan endotransglycosylases from Arabidopsis. Plant J. 1999, 18, $371-382$. [CrossRef]

41. Vaaje-Kolstad, G.; Farkaš, V.; Hrmova, M.; Fincher, G.B. Xyloglucan xyloglucosyl transferases from barley (Hordeum vulgare L.) bind oligomeric and polymeric xyloglucan molecules in their acceptor binding sites. Biochim. Biophys. Acta Gen. Subj. 2010, 1800, 674-684. [CrossRef]

42. Torres, C.R.; Hart, G.W. Topography and polypeptide distribution of terminal N-acetylglucosamine residues on the surfaces of intact lymphocytes. Evidence for O-linked GlcNAc. J. Biol. Chem. 1984, 259, 3308-3317. [CrossRef]

43. Seifert, G.J. On the potential function of type II arabinogalactan O-glycosylation in regulating the fate of plant secretory proteins. Front. Plant Sci. 2020, 11. [CrossRef] [PubMed]

44. Velasquez, S.M.; Ricardi, M.M.; Dorosz, J.G.; Fernandez, P.V.; Nadra, A.D.; Pol-Fachin, L.; Egelund, J.; Gille, S.; Harholt, J.; Ciancia, M.; et al. O-glycosylated cell wall proteins are essential in root hair growth. Science 2011, 332, 1401-1403. [CrossRef]

45. Tan, L.; Varnai, P.; Lamport, D.T.; Yuan, C.; Xu, J.; Qiu, F.; Kieliszewski, M.J. Plant O-hydroxyproline arabinogalactans are composed of repeating trigalactosyl subunits with short bifurcated side chains. J. Biol. Chem. 2010, 285, 24575-24583. [CrossRef] [PubMed]

46. Nguema-Ona, E.; Vicré-Gibouin, M.; Gotté, M.; Plancot, B.; Lerouge, P.; Bardor, M.; Driouich, A. Cell wall O-glycoproteins and N-glycoproteins: Aspects of biosynthesis and function. Front. Plant Sci. 2014, 5, 499. [CrossRef] 
47. Ruíz-May, E.; Thannhauser, T.W.; Zhang, S.; Rose, J.K.C. Analytical technologies for identification and characterization of the plant N-glycoproteome. Front. Plant Sci. 2012, 3, 150. [CrossRef]

48. Riley, N.M.; Hebert, A.S.; Westphall, M.S.; Coon, J.J. Capturing site-specific heterogeneity with large-scale N-glycoproteome analysis. Nat. Commun. 2019, 10, 1-13. [CrossRef] [PubMed]

49. Stavenhagen, K.; Hinneburg, H.; Kolarich, D.; Wuhrer, M. Site-specific N and O-Glycopeptide analysis using an integrated C18-PGC-LC-ESI-QTOF-MS/MS approach. Methods Mol. Biol. 2016, 1503, 109-119. [CrossRef]

50. An, H.J.; Froehlich, J.W.; Lebrilla, C.B. Determination of glycosylation sites and site-specific heterogeneity in glycoproteins. Curr. Opin. Chem. Biol. 2009, 13, 421-426. [CrossRef]

51. Wilkinson, H.; Saldova, R. Current methods for the characterization of O-glycans. J. Proteome Res. 2020, 19, 3890-3905. [CrossRef]

52. Mewono, L.; Nguema-Ona, E.; Gotté, M.; Koroney, A.S.; Gueye, M.F.; Driouich, A.; Vicré-Gibouin, M.; Aboughe-Angone, S. O-glycosylation in plant and mammal cells: The use of chemical inhibitors to understand the biosynthesis and function of O-glycosylated proteins. Plant Sci. Today 2015, 2, 43-51.

53. Muthu, M.; Chun, S.; Gopal, J.; Anthonydhason, V.; Haga, S.W.; Devadoss, A.J.P.; Oh, J. Insights into bionformatic applications for glycosylation: Instigating an awakening towards applying glycoinformatic resources for cancer diagnosis and therapy. Int. J. Mol. Sci. 2020, 21, 9336. [CrossRef] [PubMed]

54. Frank, M.; Schloissnig, S. Bioinformatics and molecular modeling in glycobiology. Cell. Mol. Life Sci. 2010, 67, $2749-2772$. [CrossRef]

55. Park, S.; Lee, J.; Qi, Y.; Kern, N.R.; Lee, H.S.; Jo, S.; Joung, I.; Joo, K.; Lee, J.; Im, W. CHARMM-GUI Glycan Modeler for modeling and simulation of carbohydrates and glycoconjugates. Glycobiology 2019, 29, 320-331. [CrossRef]

56. Turupcu, A.; Diem, M.; Smith, L.J.; Oostenbrink, C. Structural aspects of the O-glycosylation linkage in glycopeptides via MD simulations and comparison with NMR experiments. Phys. Chem. 2019, 20, 1527-1537. [CrossRef]

57. Johnson, K.L.; Cassin, A.M.; Lonsdale, A.; Bacic, A.; Doblin, M.S.; Schultz, C.J. Pipeline to identify hydroxyproline-rich glycoproteins. Plant Physiol. 2017, 174, 886-903. [CrossRef]

58. Willems, P.; Horne, A.; Van Parys, T.; Goormachtig, S.; De Smet, I.; Botzki, A.; Van Breusegem, F.; Gevaert, K. The plant PTM viewer, a central resource for exploring plant protein modifications. Plant J. 2019, 99, 752-762. [CrossRef]

59. Lemmin, T.; Soto, C. Glycosylator: A phyton framework for the rapid modeling of glycans. BMC Bioinform. $2019,20,513$. [CrossRef] [PubMed] 